\title{
REVIEW: FROM SCREENING TO APPLICATION OF MOROCCAN DYEING PLANTS: CHEMICAL GROUPS AND BOTANICAL DISTRIBUTION
}

\author{
IMANE ALOUANI, MOHAMMED OULAD BOUYAHYA IDRISSI, MUSTAPHA DRAOUI, MUSTAPHA BOUATIA \\ Laboratory of Analytical Chemestry, Faculty of Medicine and Pharmacy, Mohammed V University in Rabat \\ Email: imane.alouani@itech.fr
}

Received: 19 May 2016 Revised and Accepted: 12 Aug 2016

\begin{abstract}
Many dyes are contained in plants and are used for coloring a medium. They are characterized by their content of dyes molecules. They stimulate interest because they are part of a sustainable development approach. There are several chemicals families of plant dye which are contained in more than 450 plants known around the world. In this article, a study based on literature allowed us to realize an inventory of the main dyes plants potentially present in Morocco. A list of 117 plants was established specifying their botanical families, chemical Composition, Colors and parts of the plant used.
\end{abstract}

Keywords: Natural dye, Morocco, Chemical structures, Plant pigments, Extraction

(C) 2016 The Authors. Published by Innovare Academic Sciences Pvt Ltd. This is an open access article under the CC BY license (http://creativecommons. org/licenses/by/4. 0/)

DOI: http://dx.doi.org/10.22159/ijpps.2016v8i10.12960

\section{INTRODUCTION}

Several hundred species of plants are used around the world sometimes for thousands of years for their ability to stain a medium or material[1]. The demand for natural colors in the world is around 10000 tons, equivalent to $1 \%$ of the world consumption of synthetic dye [2]. The interest for natural products is experiencing a major craze in this sense that we undertake the study of vegetable dyes.

These plants produce substances, which filter photons, absorb part of the light and reflect the rest of the light spectrum in variable wavelength [3]. A dye plant is a plant able to produce by biosynthesize soluble dyes molecules "dyes" or insoluble compounds "Pigments/lacquers"[4]. These compounds are extracted and used for dyeing various materials, manufacturing colored food, cosmetics, inks or paints [5]. The dye molecules are either contained in the leaves (Indigo), flowers (Saffron), fruits (Walnut stain) or seeds (Annatto), roots (Curcuma), wood (logwood), or the sap (Dragon) [6-8].

In Morocco, some dye plants represent our customs and traditions worldwide. Such as Henna (Lawsonia inermis)[6], which is used to color the skin and hair. Or Saffron (Crocus sativus)[6], which in addition to its unique taste, is used to color foods.

But the most representative example of using dye plants in Morocco is "traditional tanneries of Fez Chouara" that treat and colors the skins of animals. The dyeing is done in a traditional tank with only natural dyes mostly extracted from plants such as: Papaver rhoeas or red poppy for the Red hue, Indigofera tinctoria SP gives the Blue tint, Lawsonia inermis $L$. for its Orange dye, or Mentha for the green.

Since its discovery in the 18 th century by W. H. Perkin $[9,10]$, the synthetical dye replaced all the natural dyes. The reason is that the natural dyes are very expensive and rare but mainly difficult to use, with bad properties such as fastness to light and low vividness [11]. But the interest in natural dyes takes a new breath. And more specifically the dye plants that contain the most important natural dye with a large range compared to the animals and minerals [5]

In addition to presenting many advantages such as a high diversity and complexity of nuances [7], the use of vegetable dyes mainly falls within a sustainable development approach. They are known to be less toxic, less polluting, safer, non-carcinogenic and non-poisoning
[5]. They are also biodegradable and compatible with the environment [12].

In this article, we process methods of extraction and analysis, applications, and different families of natural dyes. Finally, we give examples of dye plants and their chemical compositions and propose a non-exhaustive list of existing dye plants in Morocco could be used for various applications.

For this review, we have grouped a large number of information concerning dye plants. The studies were initially focused on the historical data through works relating the history and evolution of their use since the Stone Age like a wall painting art to more modern use as Dye-Sensitized Solar Cells (DSCC). To make a complete and wide inventory of dye plants existing in the world, we were interested in the studies in the various domains of use: textile, pharmaceutical, DSSC, cosmetic or other.

The most used keywords are Dyes, Naturals dyes, Dyeing plants pigments, the Plant pigments, or the botanical name of the plant. Data chosen at this stage was only from the scientific article, scientific work or a botanical association: a collection of dye plants of the city of Namur. A database of 311 plants was created containing the following data. As regards the list of the Moroccan plants, it was obtained by crossing a large number of ethnobotanical studies in Morocco with our database. The result is a not exhaustive list of 117 dye plants, which are present in Morocco.

Preparation of natural dyes from plants: parameters and methods

Getting a vegetable dye from plants is by extraction. This is the method by which the active ingredient is removed from the plant after treatment with a specific solvent or solvent mixture. A natural dye is usually prepared by boiling the ground powder in a solvent, or a solvent mixture. But sometimes it is left to macerate in cold water. Vegetable dye is extracted by several methods, which may be very simple (decoction of the plant) or extremely complex and long (soaking, fermenting, drying, etching through metal salts) [5, 13].

Several parameters have an important role in the extraction of coloring principle and can change the Colors obtained significantly:

- The part of the plant used: leaves, roots, bark, berries, heart trunk, flowers, stigma, aerial parts of the plant and sometimes the entire plant [4-6]. 
- The characteristics of the plant: the origin of the plant variety, the harvest season, climate and environmental conditions, the geographical location, the different diseases that can affect the plant, the plant maturity and shelf life [14].

- The extraction techniques: The media type (Aqueous/organic solvent or acid/base), the $\mathrm{pH}$ of the medium and the extraction conditions such as temperature, time, hardware, bath ratio and the grain size of the substratum [11].

- The protocol of extractions: agitation, reflux heating or extraction soxhlet [15]

- The mordant or substrate is used to form a lacquer: a large number of dye molecules can be combined with various metal salts as their structure has one or more chelating sites (term characterizing the complexation of a dye with metal). Especially use of metal ions such as $\mathrm{Al}$ (III), $\mathrm{Cr}$ (VI), $\mathrm{Cu}$ (II), Fe (II) and $\mathrm{Sn}$ (III). Mordanting iron and copper alters the color rendering darker, unlike mordant aluminum $[6,11]$.

The extraction is a process that includes transferred masses since the dye molecule is bound to the cell membrane of the plant, which can be a problem. The extraction mechanism is as follows: the disruption of the cell wall; the release of the dye molecule; and the migration to the external environment. New technologies allow for improvement.

However, is required maintain the intact molecule to use it. Table 1 contains some example of some extraction methods [2]. These technologies include the use of ultrasound for excellent returns. Ultrasonic wave's properties, essentially cavitation are applied for years in the plant matrices to improve the classical extraction methods. Its use is experiencing a significant increase either in the laboratory or in the industry since it reduces the processing time with yield increasingly important active ingredients. The effectiveness of ultrasound is now applied to the extraction of colors, flavors, polyphenols, as well as many pharmacological substances [2, 15]

\section{Use natural dyes of plant origin}

A dye is a substance that can be used to impart color to other materials such as textiles, papers, and foodstuffs [5]. Natural dyes are used nowadays in many areas from the most traditional to the most innovative: textile industry, the pharmaceutical industry, cosmetic industry, confectionery, food colors, and stationery as a diagnostic agent or as an antibacterial in many products.

Thanks to their nature environmentally friendly, vegetable dyes open the field to several uses especially for applications that require non-toxic products [2].

Table 1: A literature review of some extraction methods

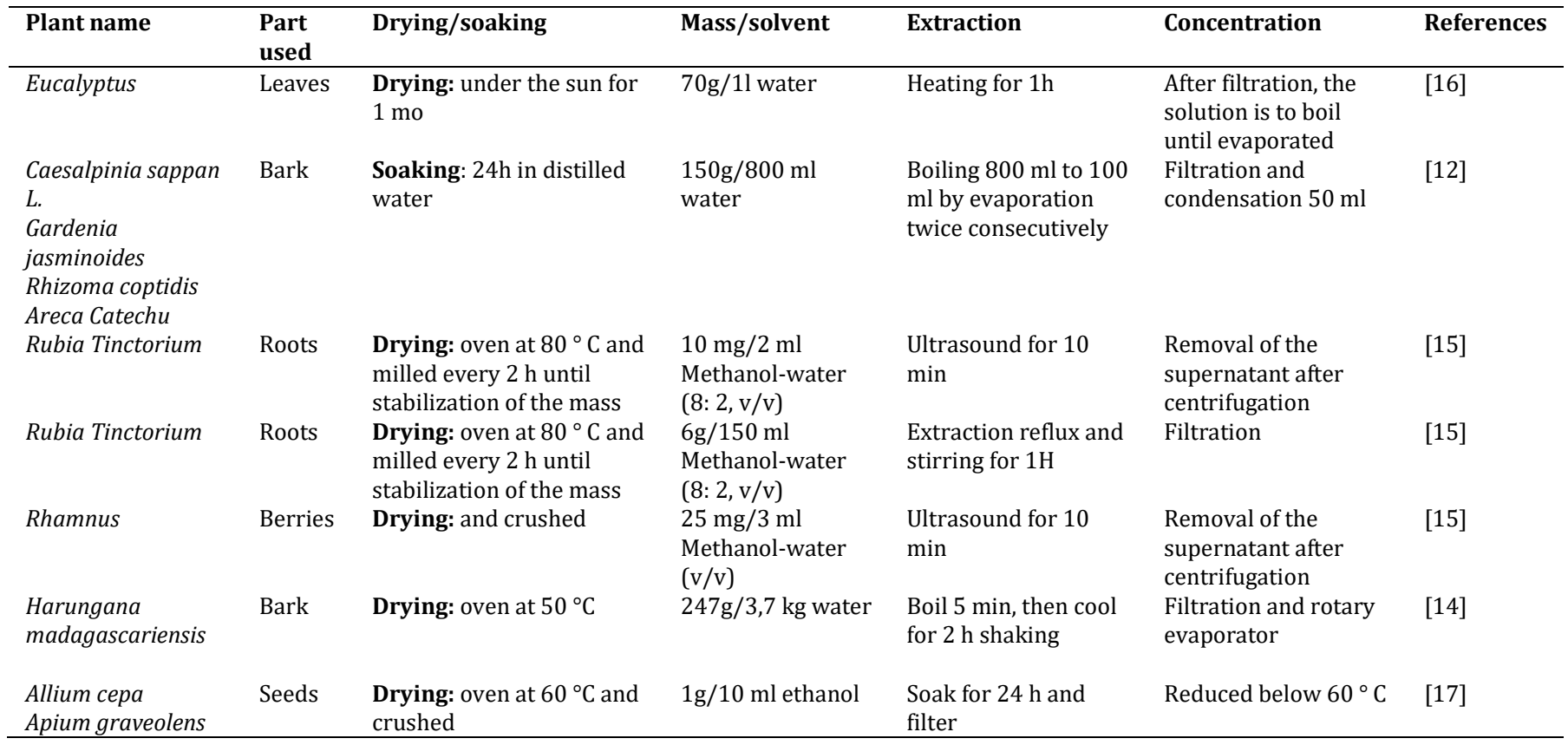

Table 2: Classifications of natural dyes by Codex Alimentarius [3, 27, 28]

\begin{tabular}{|c|c|c|c|c|c|}
\hline Color & Source plant & $\mathrm{N}^{\circ} \mathrm{CE}$ & Common name & $\begin{array}{l}\text { Color } \\
\text { Index }\end{array}$ & Some food uses \\
\hline Yellow & Roots of Curcuma Longa L. & E100 & Curcumine & 75300 & $\begin{array}{l}\text { Curry, green mustards, soups, syrups, Salam, } \\
\text { dairy products. }\end{array}$ \\
\hline $\begin{array}{l}\text { Yellow to } \\
\text { red Variable }\end{array}$ & $\begin{array}{l}\text { Starting strain of edible } \\
\text { carrots, vegetable oils, grass, } \\
\text { lucerne and nettle. } \\
\text { Annatto } \\
\text { Paprika }\end{array}$ & $\begin{array}{l}\text { E160a(i) } \\
\text { E160b } \\
\text { E160c }\end{array}$ & $\begin{array}{l}\text { A: mixed carotenoids } \\
\text { B: Rocou, Bixine, } \\
\text { Norbixine } \\
\text { C: Paprika extract, } \\
\text { Capsanthine, } \\
\text { Capsorubine }\end{array}$ & $\begin{array}{l}75130 \\
75120 \\
-\end{array}$ & $\begin{array}{l}\text { Drinks, liqueurs, syrups, soups, condiments, } \\
\text { ice cream. }\end{array}$ \\
\hline Green & $\begin{array}{l}\text { Starting edible herb strain, } \\
\text { alfalfa and nettle }\end{array}$ & E140 & $\begin{array}{l}\text { Chlorophylle (i) } \\
\text { NB: le ii (75815) } \\
\text { Synthetic is developed } \\
\text { from natural }\end{array}$ & 75810 & $\begin{array}{l}\text { Green vegetables and fruit to be stored in a } \\
\text { liquid, dairy products, delicatessen products } \\
\text { and envelope products. }\end{array}$ \\
\hline Black & Carbo medicinalis vegetalis & E153 & Vegetable carbon & - & $\begin{array}{l}\text { Deli meats and envelopes, and caviar } \\
\text { substitutes, confectionery, candied fruit, } \\
\text { desserts, syrups. }\end{array}$ \\
\hline
\end{tabular}


In textile and leather industries, the vegetable dyes are the best known and most used for thousands of years as evidenced by archaeological discoveries in Egypt which confirms the use of plants such as Henne, Safran and Curcuma [18]. They are still present in this area. There are many types of plants such as Gaude, Pastel or Indigo, which are used for dyeing various textile materials: Cotton, wool or silk [7, 8, 11, 19-23].

However, vegetable dyes, although it is renewable and biodegradable sources, can cause over-exploitation of natural resources and lead to deforestation. For this reason, the Global Organic Textile Standard (GOTS) allowed the use of synthetic dyes and banned the use of endangered plants [13].

The usual and known application of dye plants is the food industry. In recent decades, the consumption of natural dyes is increasingly important. Especially in preserves, confectionery, beverages, but also in the deli, butterfat (oil, butter, cheese, and sugar) [3]. The use of these dyes is strictly regulated internationally by the Food and Agriculture Organization (FAO), and the World Health Organization (WHO), or European level according to a strict protocol: CODEX ALIMENTARIUS that includes a large number of establishments. The principle of "positive list" is applied to all food colors, which means that what is not allowed is tacitly prohibited. They are provided with a code number preceded by the letter E1XX which $\mathrm{x}$ represents a number as shown in table 2 [3, 24-26].

In the pharmacological field, the majority of dye plants have medicinal properties. In addition to their nontoxic character, natural dyes are excellent candidates for many applications in the production of drugs. They are used to Coloring gelatin capsules shells, as well as the process for coating tablets and pills [5].

The cosmetic is also characterized by the use of vegetable dyes and this since ancient times. Henna is the best-known plant in the world for its ability to color the hair, skin and even nails. But this is not the only one since natural dyes are used for makeup (Eyeshades, red lipstick.), for care, toothpaste mouthwashes, and several other 1 'r applications [5, 29-31].

DSSC (Dye-Sensitized Solar Cell) or Grätzel cell is a photoelectrochemical system based on plant photosynthesis, which exposed to light, produces electricity. Several interesting tracks including natural dyes were explored: the molecules of the group tannins, anthocyanins, carotenoids or chalone and many other compounds sometimes extracted from plant seeds answered as celery or onion. Natural dyes are a less expensive alternative, faster, environmentally friendly and low energy consumption for photosensitive pigment cell (DSSC) compared to the ruthenium complex $[17,21,32]$.

Another use is possible for natural dyes: In histology (bone coloring, nuclear staining) for diagnostic deficiencies kidney or liver and even other body tissues. Such as Inulin to make a diagnostic of the kidneys that are not metabolized by the body, or the Rose Bengal, which is used for the liver is to be disposed into 1 minute [5].

By coupling the antibacterial characteristics and its power dyes, natural dyes can be used to offer innovative products such as antibacterial textiles [21].

\section{Characterization of dyes}

The natural dyes from plants have the ability to color a solid or liquid substance [5]. Unlike the synthetic dyes, the color is obtained by a combination of molecules contained in the plant [1]. They are formed by atoms of carbon, hydrogen, oxygen and interconnected by single or double bonds forming an electrons flow over molecular orbital " $\Pi$ ".

Every molecule absorbs specific frequencies that are characteristics of their structures. When the molecules are excited, the energy produced is re-emitted as radiation in a wavelength, which determines the color. For example, if the radiation is in the visible area around 600 to $700 \mathrm{~nm}$ the color is red.

\section{Principal chemical groups of a dye molecule}

The coloring properties of an organic compound are determined by the chemical structure of the dye molecule. Most of them are unsaturated and aromatic organic molecules. As far as the chemistry of dyes is concerned, a dye molecule has three principal chemical groups: Auxochrome, Chromophore, and solubilizing group. They are represented in fig. $1[5,33]$.

The solubilizing group will improve the solubilizing ability of the dye molecule in various substances. This is the main estate of a dyestuff contrary to the pigments that are insoluble $[3,5,33]$.

The auxochrome group corresponds to the $\mathrm{OH}$ groups, amine groups $\mathrm{NH}_{2}, \mathrm{COOH}$ and $\mathrm{SO}_{3} \mathrm{H}$ group. These are the ionizable portions of the dye, which will allow the fixing of the dyestuff to the support. This characteristic is very important for dyeing fabrics but not really used in cosmetics or paint $[3,5,33]$.

The chromophore group is responsible for the color. Once degraded, the molecule loses its coloring power. This optical property is resulting from the energy absorption in a range of the visible spectrum, while the other wavelengths are transmitted or diffused $[3,5,33]$.

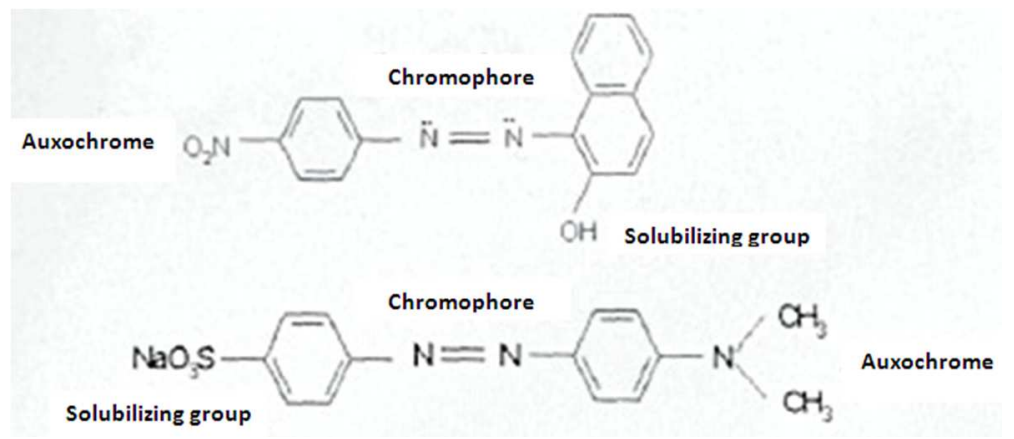

Fig. 1: Principal chemical groups: chromophore, auxochromes et solubilizing group [6]

\section{Classification of natural dyes}

The dyes can be classified according to several criteria: Depending on the chemical structure, and depending on the color [1]. In this article, we will focus only on the chemical composition of plants $[1,6,13]$.

\section{i. Quinone dyes}

These are aromatic diketones derived from the oxidation of the diphenol. They are divided into different groups according to their core as shown in the fig. 2: Benzoquinones: (unicycle); Naphthoquinones (bicyclic); Anthraquinones (tricyclic) [6].

These molecules represent three basic structures, which are met in Quinone dye. They are colorless themselves, but the more they are connected to a chemical substituent (in particular the hydroxyl radical $\mathrm{OH}$ ) the more compounds are intensely colored [6].

Benzoquinones is a Quinone with a single benzene ring. Because of their simple structure, benzoquinones are highly unstable 
substances, which are rarely found in pure form in plants, especially in vascular plants.<smiles>O=C1C=CC(=O)C=C1</smiles><smiles>O=C1C=CC(=O)c2ccccc21</smiles><smiles>O=C1c2ccccc2C(=O)c2ccccc21</smiles>

Fig. 2: Chemical structures of Quinones: benzoquinones, Naphthoquinones and Anthraquinones [6]

Naphthoquinones, especially the p-(or 1.4)-naphthoquinones, which are found among the plants. The alkannin is the main dye in the Roots Alkanet and Yellow Alkanet; it exists in these plants as an angelic ester. The most known naphthoquinones is 2-Hydroxy-1,4naphthoquinone known to Lawsone contained in henna (Lawsonia inermis) as shown in fig. $3[6,13]$.<smiles>O=C1CC(O)C(=O)c2ccccc21</smiles>

Fig. 3: Chemical structures of Lawsone or 2-hydroxy-1,4naphtoquinone [13]

\section{Anthraquinones}

There are several of these dyes in dyeing lichens and fungi, which are quite important in the plant kingdom [6]. They represent the largest group of red dye [3].

These compounds are characterized by good fastness to light and excellent fastness to washing in the presence of metallic mordant $[1,33]$.

\section{ii. Flavonoids}

Characterized by its yellow color, this type of dye has a particular behavior. When they are in an aqueous solution with low concentration, the most common flavonoids (flavones and flavonols), absorb light of wavelengths between 325 and $370 \mathrm{~nm}$, so they seem colorless or very lightly colored.

In some natural environment, their absorption spectrum is shifted to superior wavelengths, making them appear yellow. The explanation for the appearance of color is attributed to the aggregation of several molecules of flavonoids when they are sufficiently concentrated in a solution and/or complex formation with metal ions [6].

The different groups of flavonoids are given in fig. 4. There is a difference of light stability among several groups of flavonoids. A determining factor appears to be the presence or absence of a hydroxyl group in position 3 in the dye molecule. The absence of this group, for example, the Luteolin, or when glycosylated the dyes have a relatively good light fastness. On the contrary, flavonols as aglycones, present a free $\mathrm{OH}$ group in 3 , are degraded by light $[6,34]$.

\section{iii. Carotenoïds}

These are yellow dyes to orange-red. They are widespread in the plant kingdom where they give their Color both to the flowers (Coltsfoot, common marigold), to the fruits (tomato) and also the roots (carrot). Their names come from carotene isolated from the carrot in 1881 [1]. The color is due to the presence of longue conjugated double bond, the perfect example is Annatto and Saffron [1].

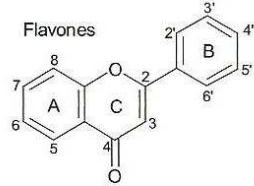<smiles>O=c1c(O)c(-c2ccccc2)oc2ccccc12</smiles>
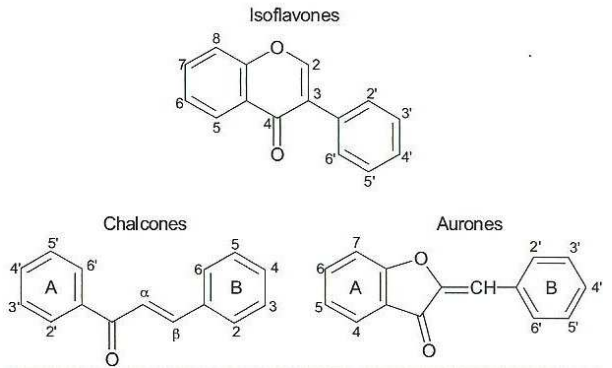

Fig. 4: Chemical structures of Flavonoids sort met in the vegetable kingdom [6]

There are different types of carotenoid:

- Bixin with the Norbixin, are present in the Achiote or Bixa orellana at a rate of over $80 \%$. Their chemical structures are given in fig. $5[6,13]$.

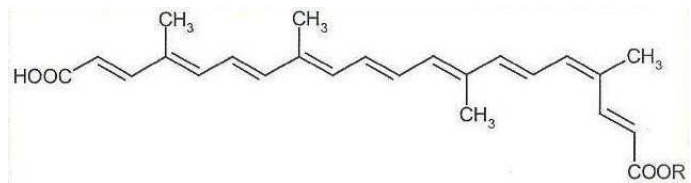

Fig. 5: Structure of Bixin $(\mathrm{R}=\mathrm{CH})$ and the Norbixin $(\mathrm{R}=\mathrm{H})$ [6]

In the saffron crocus, Crocetin is presented mostly as his di gentiobiose-ester, Crocin [6]. The different structures are given in fig. 6 and 7 :<smiles>[R]OC(=O)C(C)=CC=CC(C)=CC=CC=C(C)C=CC=C(C)C(=O)O[R]</smiles>

Fig. 6: Chemical structures of the Crocetin [6]

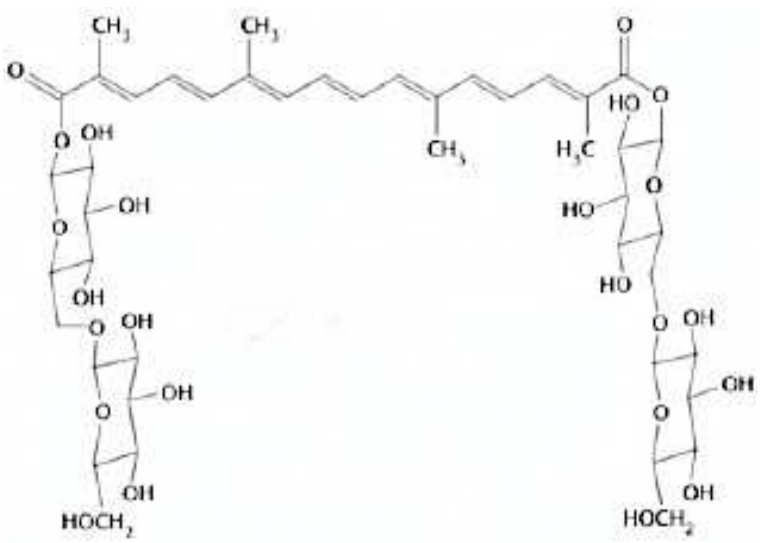

Fig. 7: Crocin structure [6] 
They are soluble in oils. These are unsaturated compounds having a plurality of conjugated double bonds whose number influences the coloring. Highly oxidized, they are easily destroyed by light $[1,6]$.

\section{iv. Tannins}

Practically all plants contain tannins. Some of them are rich enough to be used as dyeing plants. They are not usually distributed in the plant and are extracted as a specific part [13], for example [6]:

- Bark: mainly used those Oak, Pine, Alder, or Acacia;

- Wood: it operates mainly chestnut or acacia catechu (Acacia catechu);

- Leaves: using various Sumac (Rhus sp.) or The tea plants;

- Fruits: they have used Sappan beans (Brazil wood) or Bark grenades.

The tannins are polyphenolic compounds that can be divided into two groups: hydrolyzable tannins and condensed tannins as shown in fig. 10 [6].

Tannins hydrolyzable: formerly called "tannins pyrogallic" are esters. Under the action of a dilute acid or an enzyme (tannase), they hydrolyze to release a phenolic acid and another compound (generally sugar). There are two main families [6]:

Gallotins are producing Gallic acid as shown in fig. 8 and Di-Gallic acid. In most structures, a central molecule is linked to several groups Gallolyl ester [6].<smiles>[R]OC(=O)c1cc(O)c(O)c(O)c1</smiles>

Fig. 8: Gallic acid [6]
Ellagitannins: their acid hydrolysis product of Ellagic acid as shown in fig. 9.<smiles>O=c1oc2c(O)c(O)cc3c(=O)oc4c(O)c(O)cc1c4c23</smiles>

Fig. 9: Ellagic acid [6]

Tannins condensed are flavonoid derivatives. They are not decomposed by hydrolysis. On the contrary, heating in an acidic environment, they polymerize forming insoluble compounds. So it belongs to the category of pigments (they will not be discussed) [22].

Tannins are water-soluble. They produce coloration with iron salts and combine with proteins and certain polyols. They are more or less soluble in hydrophilic solvents (for example alcohol or ketone), but insoluble in hydrocarbons, oils, fats, and waxes. Aqueous solutions are colloidal. For the stability of aqueous solutions, it is not always good, especially in boiling water and in acidic milieu.

They are very soluble in alkaline solutions, in ammonia and gives brownish precipitated with potassium dichromate or chromic acid. They precipitate the salts of heavy metals (copper, iron, lead, zinc, etc.). They form precipitates or colloidal solutions of various colors with ferric salts (known as lacquer) [6].

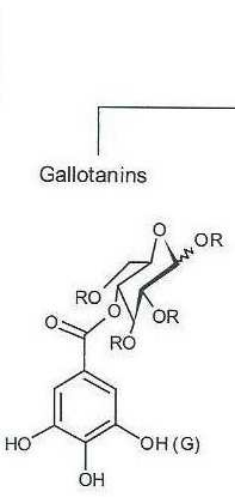

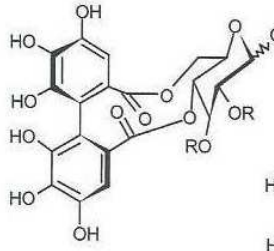

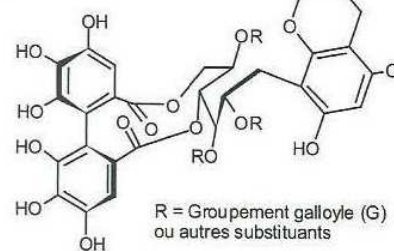

Fig. 10: Tannins classification [6]

\section{v. Indigoids dye}

This is perhaps the most important group of natural dyes, obtained from indigo plants. These involve a heteroside form of colorless Indoxyl from which the indigo dyes are biosynthesized [13].

Very few colored pale yellow tint; it is mainly present in the leaves. Indican is the first of these precursors have been identified Indigofera which is different from the one found in Reseda luteola or Isatis tinctoria L. (Isatan B) [6].
The color indigo is composed of several dye molecules produced from the Indoxyl. Indeed, whatever the glycoside present in the plant that will give precursor decomposition after enzymatic hydrolysis. Indoxyl provides several components after oxidation of Indigo: the Indigotine which is the main component as shown in fig. 11 (Color Index Natural Blue 1 No. 75780) [13]; Or Isatin which is generated in accordance with temperature; or the Indirubin violet dye isomer of indigo, obtained by condensation of Isatin under unknown factors (Color Index Natural Blue 1 No 75790) [6]. Fig.12 show the different ways to synthesis indigo dyes. 
<smiles>O=C1/C(=C2\Nc3ccccc3C2=O)Nc2ccccc21</smiles>

Fig. 11: Chemical structure of indigotin (Color Index Natural Blue 1 No. 75780) [13].
The natural indigo is the largest representative of the vat dye technology for textile dyeing. The Indigo compound is insoluble, so we have to make it soluble in an alkaline environment by reduction process that produces leucoindigo.

At the output of bath, under the action of ambient oxygen, the product turns indigo on the fiber and gives a blue color. This transformation as shown in fig. 13 is visible to the naked eye [6].

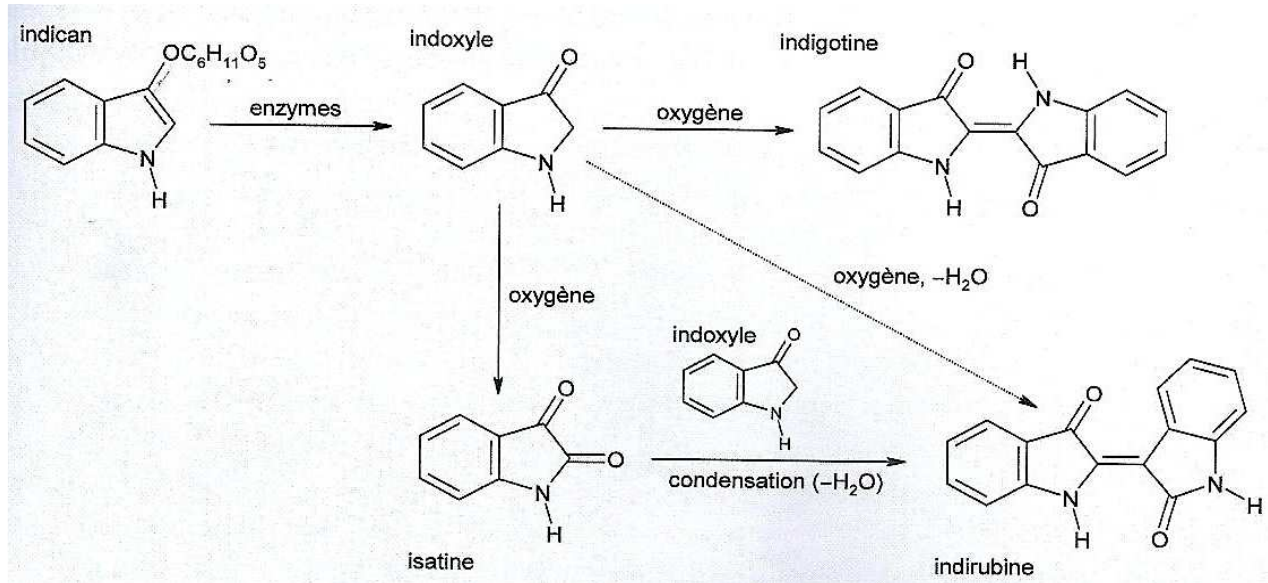

Fig. 12: Synthesis of indigo from Indican and Indoxyl [6]

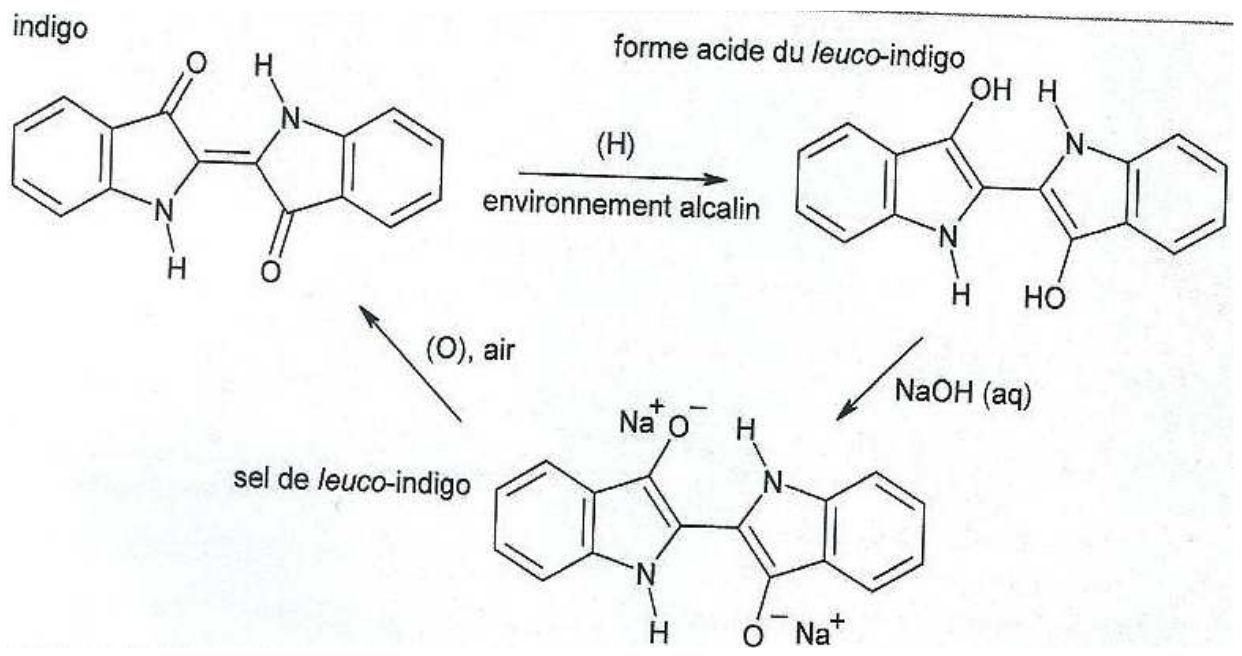

Fig. 13: Reduction of indigo to soluble Leuco-indigo salt through acid leu co indigo and regeneration of the insoluble pigment by the ambient oxygen [6]

\section{The dyeing plant in morocco}

There are numbers of important dye plants producing several colors like red, yellow, blue, black or brown. These colors can be achieved using one or more plant parts either roots, leaves, flowers, wood, seeds. About 2000 pigments are obtained from plants and nearly 150 pigments were used. In India, there are around 450 plants are known for their dyeing characters [7].

In Morocco, several plants are used as a natural dye. But they are little known because the majority of dye plants are classified as Medicinal and Aromatic Plants and some of them have been identified having antibacterial activity. The most used are:

- Brown-orange as: the Henne or Lawsonia Inermis L.: During times of celebration such as a wedding or the eve of a religious celebration, women tattoo their hands and feet to express their joy. This ritual has been part of Moroccan customs for centuries. Henna is also often used for coloring hair. It is widely used by Moroccan women of all ages and was imitated worldwide. Using Henna with different dye plants such as onion peel, Pomegranate or other plants, this blend gives various shades from red to dark brown. The leaves of this shrub contain a dye of the most important principles: Lawson (or Isojuglone). This is an orange-red naphthoquinone, which represents about 0.5 to $3 \%$ by weight of the dried sheet.

As with all natural dyes, a second naphthoquinone, the iso plumbagin is present with Lawsone in the bark of the trunk and branches. But in the leaves is also found flavonoids yellow colors such as Luteolin, Apigenin; And tannins in the bark of twigs (5\% to $10 \%$ Gallic acid), which play a role of organic mordant and contribute to the final color. 
- Red as: Saf. flower of or Carthamus tinctorius L.: Carthamin, extracted from the flowers without the heads, is a red dye of Safflower. This is a quinoa chalcone C-glucoside which is biosynthesized by the end of flowering, from a yellow precursor, précarthamine. Other minor red pigments, compositions close to Carthamin were identified. Carthamin is the Colour Index Natural Red 26 (CI75140).

- Yellow exclusive as: saffron or Crocus sativus L.: Saffron, the star of the Taliouine region of Morocco, is known for its unique composition with its many culinary and medicinal properties. In addition to its unique taste, is also used to color food, textiles or cosmetics. Morocco is the 4th exporter of Saffron the quantity varies from 2 to 3 tons of product per year $(2008 /[35])$ that is largely required for cosmetic uses, culinary or therapeutic. Its stigmas contain a soluble yellow dye in water, with a very coloring power: a small portion of saffron is enough to color yellow 100000 times its volume in water. It contains the carotenoids Crocetin (fig. 6) and digentobiosylester Crocin (fig. 7). Overall good quality saffron can contain up to $30 \%$ of its weight. They constitute el dye Color Index No: 75100 and Natural Yellow No: 6.

- Blue as: Indigofera tinctoria L.: The leaves of this shrub contain Indican which is the precursor of dye molecules composing the Indigo (see fig. 13). It decomposes into sugar and Indoxyl by enzymatic hydrolysis. By condensation of Indoxyl, one molecule of indigo is formed in the presence of oxygen. The dye molecules of indigo are the Natural Blue No: 75780 Color Index.
- Beige brown as Pedunculate oak Quercus robur L.: The oak tree is a high tree found in Europe, the Caucasus, and Morocco. One uses the bark, sold in powder form, TAN. Sometimes dry acorns pulverized are used. The bark of oak contains 12 to $16 \%$ of tannins which are a complex mixture of polyphenols, "hydrolysable tannins" especially ellagitannins and "condensed tannins" mainly procyanidins.

According to my literature research, there are no established screenings for dye plants in Morocco. Most of the scientific works are more interested in the MAP (Medicinal and Aromatic Plants). It was easier to find several ethnobotanical screening by regions of these plants. From this information and the database that I collected to come up with a non-exhaustive list of 117 dying plants, which emerge. They are distributed as follows in table 3:

Tableau 3: Botanical distribution of dye plants

\begin{tabular}{ll}
\hline Botanical family & Repartition \\
\hline Asteraceae (cf. table 4) & 22 \\
Fabaceae (cf. table 5) & 9 \\
Rosaceae (cf. table 7) & 8 \\
Fagaceae (cf. table 6) & 7 \\
Other Family (cf. table 8) & 71 \\
\hline
\end{tabular}

The database includes the following information: The botanical name, the chemical family, color and part used.

Table 4: Dye plants in morocco asteraceae family

\begin{tabular}{|c|c|c|c|c|}
\hline $\begin{array}{l}\text { Botanical } \\
\text { nomenclature }\end{array}$ & Color & Chemical composition & Parts used & Réf. \\
\hline Anthemis tinctoria & $\begin{array}{l}\text { Yellow, green, } \\
\text { Kaki }\end{array}$ & Flavonoids & Heads flowers & [4] \\
\hline Artemisia abrotanum & Yellow & Flavonoids/Aurone & $\begin{array}{l}\text { Flowers and flowering } \\
\text { branches }\end{array}$ & {$[4,36-38]$} \\
\hline Artemisia vulgaris & Yellow & Flavonoids et tannins. & Entire plant & {$[4,36,37]$} \\
\hline Bidens pilosa SP. & Yellow & Flavonoids & $\begin{array}{l}\text { Flowers and flowering } \\
\text { branches }\end{array}$ & {$[6,39]$} \\
\hline Calendula officinalis & Yellow to orange & Carotenoïds et Flavonoids & Flowers & $\begin{array}{l}{[37,38,40,} \\
41]\end{array}$ \\
\hline Calluna vulgaris & Yellow to green & Flavonoids et tannins. & Flowering branches & {$[4,39]$} \\
\hline Carthamus tinctorius & Red & $\begin{array}{l}\text { Quinochalcone } \\
\text { NY2 } 75130 \text { et } 75135 ; \text { NY27: 75125; NR26: } 75140 \\
\text { Carthamine }\end{array}$ & Flowers & $\begin{array}{l}{[6,34,40,} \\
41]\end{array}$ \\
\hline Centaurea cyanus & Blue & Anthocyanins/Cyanidine & Flowers & {$[4,34,37]$} \\
\hline Cichorium intybus & Brown, blue & Anthocyanin & Entire plant, Flowers & $\begin{array}{l}{[4,34,36,} \\
37]\end{array}$ \\
\hline Conyza canadensis & Yellow & Flavonoids et en Tannins & Flowers & {$[4,37]$} \\
\hline Coreopsis SP. & Yellow & Flavonoids: Chalcones and Aurone & $\begin{array}{l}\text { Flowers and flowering } \\
\text { branches }\end{array}$ & {$[6,37]$} \\
\hline Cynara cardunculus & Yellow & Flavonoids & Leaves & $\begin{array}{l}{[4,37,38,} \\
42]\end{array}$ \\
\hline Cynara scolymus & Yellow & Flavonoids & Leaves & {$[4,36,38]$} \\
\hline $\begin{array}{l}\text { Eupatorium } \\
\text { cannabinum }\end{array}$ & Yellow & $* \mathrm{ND}$ & Entire plant & {$[4,37]$} \\
\hline Helianthus annuus & Yellow & Flavonoids & Leaves & $\begin{array}{l}{[4,34,37,} \\
41]\end{array}$ \\
\hline Inula helenium & Yellow blue & Inuline & Roots and flowers & $\begin{array}{l}{[4,36,38,} \\
43]\end{array}$ \\
\hline Matricaria recutita & Yellow & *ND & Aerial part of the plant & $\begin{array}{l}{[4,37,38,} \\
44]\end{array}$ \\
\hline $\begin{array}{l}\text { Scabiosa/knautia } \\
\text { arvensis }\end{array}$ & $\begin{array}{l}\text { Green, blue, } \\
\text { purple }\end{array}$ & $\begin{array}{l}\text { Rich in tannins: Dipsacan and after the oxidation } \\
\text { dipsacotine }\end{array}$ & Flowers & $\begin{array}{l}{[4,39,41} \\
45]\end{array}$ \\
\hline Solidago virgaurea & Yellow & $\begin{array}{l}\text { Tannins } \\
\text { Flavonoids }\end{array}$ & Aerial parts of the plant & {$[4,6,37]$} \\
\hline Tanacetum vulgare & Yellow to brown & $\begin{array}{l}\text { Tannins } \\
\text { Flavonoids }\end{array}$ & Flowers and leaves & {$[4,38]$} \\
\hline Taraxacum sp. & Yellow, magenta & Flavonoids: Luteolin & Roots and rhizomes & {$[37,38]$} \\
\hline Tussilago farfara & Yellow & *ND & Roots and rhizomes & {$[37]$} \\
\hline
\end{tabular}

* ND: not determined. 
Table 5: Dye plants in Morocco of the Fabaceae family

\begin{tabular}{|c|c|c|c|c|}
\hline Botanical nomenclature & Color & Chemical composition & Parts used & Réf. \\
\hline Acacia dealbata & Red to brown & Tannins/proanthocyanidins. & Bark & {$[6,46]$} \\
\hline Acacia decurrens & Brown & Tannins/proanthocyanidins. & Bark & {$[2,6,46]$} \\
\hline $\begin{array}{l}\text { Acacia nilotica } L .=\text { Acacia } \\
\text { arabica }\end{array}$ & $\begin{array}{l}\text { Red, brown and } \\
\text { black }\end{array}$ & $\begin{array}{l}\text { Hydrolysable tannins and } \\
\text { tannins }\end{array}$ & Seed pods and bark & $\begin{array}{l}{[1,5-7,13,39] \mathrm{R} 13 / \mathrm{FEN}} \\
\mathrm{v} 1\end{array}$ \\
\hline Acacia pycnantha & Red to brown & Tannins/proanthocyanidins. & Bark & {$[6,46]$} \\
\hline Cytisus scoparius & Yellow to green & $\begin{array}{l}\text { Flavonoids, Carotenoïds; } \\
\text { NY2, } \\
\text { 75610: Genisteol, 75590: } \\
\text { Luteolol }\end{array}$ & $\begin{array}{l}\text { Flowers and flowering } \\
\text { branches }\end{array}$ & {$[4,6,39]$} \\
\hline Indigofera coerulea & Blue & Indigoïds: Indican & Leaves & {$[6,39]$} \\
\hline Ononis repens & Yellow & $* \mathrm{ND}$ & Flowering branches & {$[4,39]$} \\
\hline Trifolium pratense & Yellow to green & Flavonoids & Entire plant & {$[4,39,47]$} \\
\hline Trigonella foenum-graecum & Red to brown & Tannins et flavonoids & Seeds & {$[38,39,41,42,48-52]$} \\
\hline
\end{tabular}

* ND: not determined.

Table 6: Dyeing plant in morocco family Fagaceae

\begin{tabular}{|c|c|c|c|c|}
\hline $\begin{array}{l}\text { Botanical } \\
\text { nomenclature }\end{array}$ & Color & Chemical composition & Parts used & Réf. \\
\hline Castanea sativa & Brown & Tannins: NB6 gallotin acid. & Bark & {$[6,39]$} \\
\hline Quercus & Beige to dark & $\begin{array}{l}\text { Tannins/Quercitine and Flavine } \\
\text { NY10 } \\
75670 \text { Quercetol; } \\
75720 \text { Quercitrons. }\end{array}$ & Bark and leaves & {$[6,17,39]$} \\
\hline Quercus cerris $L$. & $\begin{array}{l}\text { Beige brown, grey to } \\
\text { black }\end{array}$ & Tannins & $\begin{array}{l}\text { Bark in the form of powder called } \\
\text { TAN }\end{array}$ & [6](R13) \\
\hline Quercus coccifera L. & $\begin{array}{l}\text { Beige brown, grey to } \\
\text { black }\end{array}$ & Tannins & $\begin{array}{l}\text { Bark in the form of powder called } \\
\text { TAN }\end{array}$ & $\begin{array}{l}{[6,22,38,39,51,} \\
53]\end{array}$ \\
\hline Quercus iles $L$. & $\begin{array}{l}\text { Beige brown, grey to } \\
\text { black }\end{array}$ & Tannins & $\begin{array}{l}\text { Bark in the form of powder called } \\
\text { TAN }\end{array}$ & {$[6,39]$} \\
\hline Quercus robur & $\begin{array}{l}\text { Beige brown, grey to } \\
\text { black }\end{array}$ & Tannins & Bark & {$[4,6,36]$} \\
\hline Ulex Parviflorus & ND & $\begin{array}{l}\text { Flavones, Chalcones et carotenoïds. } \\
\text { Genistein, 7-O-glucoside of } \\
\text { Genistein. }\end{array}$ & Bark & {$[6,37]$} \\
\hline
\end{tabular}

* ND: not determined.

Table 7: Dye plants in morocco of the rosaceae family

\begin{tabular}{|c|c|c|c|c|}
\hline $\begin{array}{l}\text { Botanical } \\
\text { nomenclature }\end{array}$ & Color & $\begin{array}{l}\text { Chemical } \\
\text { composition }\end{array}$ & Parts used & Ref. \\
\hline Agrimonia eupatoria & Yellow, green, brown & Tannins & Entire plant or leaves & {$[4,39]$} \\
\hline Alchemilla vulgaris & Light orange & Tannins & Entire plant & {$[4,39]$} \\
\hline Malus domestica & Yellow & Flavonoids & Bark & {$[7,34,41]$} \\
\hline Prunus amygdalus & Green & $*$ ND & The shell of the kernel & {$[36,38,42,51]$} \\
\hline Prunus padus & $\begin{array}{l}\text { Orange to brown, purple and } \\
\text { grey. }\end{array}$ & Anthocyanins & Fruits, branches and bark. & {$[4,39]$} \\
\hline Prunus spinosa & Blue, Pink & $* \mathrm{ND}$ & Fruits & $\begin{array}{l}{[4,36,38,39,41,} \\
42]\end{array}$ \\
\hline Rosa damascena Mill & ${ }^{*} \mathrm{ND}$ & $\begin{array}{l}\text { Carotenoids: } \\
\text { Quercitin }\end{array}$ & Flowers & {$[40,42,43,54]$} \\
\hline Rubus fruticosus & Purple and blue, gray & $\begin{array}{l}\text { Anthocyanins, } \\
\text { tannins }\end{array}$ & $\begin{array}{l}\text { Leaves, branches, fruit, roots and } \\
\text { rhizomes. }\end{array}$ & {$[4,34,36,38]$} \\
\hline
\end{tabular}

* ND: not determined.

Table 8: Dye plants in Morocco other botanical families

\begin{tabular}{|c|c|c|c|c|c|}
\hline Botanical Family & $\begin{array}{l}\text { Botanical } \\
\text { nomenclature }\end{array}$ & Color & Chemical composition & Parts used & Réf. \\
\hline Adoxaceae & Sambucus nigra & Blue, purple, green & Anthocyanins & Leaves and berries & {$[4,44]$} \\
\hline Amaranthaceae & $\begin{array}{l}\text { Beta vulgaris subsp. } \\
\text { Vulgaris }\end{array}$ & Red & Betanine not listed. & Roots & {$[27,28,39]$} \\
\hline Amaryllidaceae & Allium сера & Yellow, green, orange & $\begin{array}{l}\text { Flavonoids, tannins, and } \\
\text { anthocyanins. }\end{array}$ & The onion skin & $\begin{array}{l}{[4,17,34,36,} \\
38,43]\end{array}$ \\
\hline Anacardiaceae & Pistacia terebinthus $L$. & Yellow & $\begin{array}{l}\text { Anthocyanins, tannins: } \\
\text { Myrisitine; Gallotanique } \\
\text { acid }\end{array}$ & Leaves and galls & {$[39,55]$} \\
\hline
\end{tabular}




\begin{tabular}{|c|c|c|c|c|c|}
\hline & Rhus [52] Pentaphylla & $\begin{array}{l}\text { Beige brown, grey to } \\
\text { black }\end{array}$ & $\begin{array}{l}\text { Tannins: Gallotanins } \\
\text { Myricetine }\end{array}$ & Leaves & $\begin{array}{l}{[4,13,36,39,} \\
51,52]\end{array}$ \\
\hline \multirow{4}{*}{ Apiaceae } & Anthriscus sylvestris & Yellow & Flavonoids: Luteolin & Leaves & {$[4,39]$} \\
\hline & Apium graveolens & Yellow & Flavonoids: Luteolin & Leaves & {$[17,36,39,43]$} \\
\hline & Daucus carrota & Yellow & Carotenoids et anthocyanins & Rhizomes and roots & {$[4,34,36,39]$} \\
\hline & Petroselinum crispum & Yellow & $* \mathrm{ND}$ & Leaves & {$[4,36,39]$} \\
\hline Araliaceae & Hedera helix & Violet blue & Anthocyanins & Fruits & {$[4,36,39]$} \\
\hline Berberidaceae & Berberis vulgaris & Yellow & Berberine & $\begin{array}{l}\text { Bark, roots, stems } \\
\text { and leaves and } \\
\text { berries }\end{array}$ & {$[4,13,36]$} \\
\hline \multirow[t]{2}{*}{ Betulaceae } & Alnus glutinosa & $\begin{array}{l}\text { Yellow, kaki, brown, } \\
\text { black }\end{array}$ & Tannins et flavonoids & Leaves, bark & {$[1,4,6,7,39]$} \\
\hline & Betula pendula & Yellow to brown & Tannins & $\begin{array}{l}\text { Leaves, branches, } \\
\text { and bark. }\end{array}$ & {$[4,39]$} \\
\hline \multirow[t]{4}{*}{ Boraginaceae } & Alkanna tinctoria & $\begin{array}{l}\text { Carmine to dark } \\
\text { purple }\end{array}$ & $\begin{array}{l}\text { Naphtoquinones. } \\
\text { NR20 } 75535 \text { Alkannine }\end{array}$ & Roots & {$[6,39,55]$} \\
\hline & Echium vulgare & Violet & $* \mathrm{ND}$ & Roots and rhizomes & {$[4,39]$} \\
\hline & Onosma Fastigiata & Violet & Anthraquinones & Roots & {$[6,39]$} \\
\hline & Origanum vulgare & Violet rouge & Anthraquinones & Leaves & {$[4,36,39,44]$} \\
\hline Brassicaceae & Isatis tinctoria $L$. & Blue & Indigotine & Leaves & {$[4,6,39]$} \\
\hline Cesalpiniaceae & Caesalpinia spinosa & Black & Hydrolysable tannins & Cloves & {$[6,56]$} \\
\hline \multirow{2}{*}{ Chenopodiaceae } & Chenopodium album & Yellow and green & $* \mathrm{ND}$ & Aerial Parts & {$[4,36,39,51]$} \\
\hline & Spinacia oleracea & Yellow to brown & Carotenoids & Leaves & {$[4,31,39,43]$} \\
\hline Clusiaceae & $\begin{array}{l}\text { Hypericum } \\
\text { perforatum }\end{array}$ & Yellow, orange, green & Anthraquinones: hypericin & $\begin{array}{l}\text { Entire plant and } \\
\text { flowers }\end{array}$ & {$[4,39]$} \\
\hline Cupressaceae & Juniperus Communis & $\begin{array}{l}\text { Ocher, apricot brown, } \\
\text { gold or purple }\end{array}$ & $* \mathrm{ND}$ & Fruits and branches & {$[4,36,39,44]$} \\
\hline Dennstaedtiaceae & Presidium aquiline & $\begin{array}{l}\text { Yellow, green brown, } \\
\text { grey, black }\end{array}$ & Flavonoids et tannins & Roots and rhizomes & {$[4,39]$} \\
\hline Dryopteridaceae & Dryopteris filix-mas & Brown, grey, black & Condensed tannins & Roots and rhizomes & {$[4,39]$} \\
\hline Ericaceae & Arbutus unedo & Yellow to grey & Tannins & $\begin{array}{l}\text { Flowering branches } \\
\text { bark and leaves. }\end{array}$ & {$[4,39]$} \\
\hline Euphorbiaceae & $\begin{array}{l}\text { Chrozophora } \\
\text { tinctoria (L.) }\end{array}$ & Green, Blue, violet & Anthraquinones flavonoids & Leaves & {$[5,7,39,57]$} \\
\hline Gramineae & Phragmites australis & Yellow & Flavones: Tricine. & Aerial parts & {$[4,36,37]$} \\
\hline Herbaceae Rubiaceae & Rubia tinctorium & Red to orange & $\begin{array}{l}\text { Anthraquinone: Alizarin and } \\
\text { Purpurin }\end{array}$ & $\begin{array}{l}\text { Rhizomes contain a } \\
\text { red pigment }\end{array}$ & $\begin{array}{l}{[1,4,7,13,36,} \\
39]\end{array}$ \\
\hline \multirow[t]{2}{*}{ Iridaceae } & Crocus sativus & Yellow & $\begin{array}{l}\text { Carotenoïds } \\
\text { NY6, } 75100 \text { Crocetine. }\end{array}$ & $\begin{array}{l}\text { Red stigmas of the } \\
\text { flower }\end{array}$ & $\begin{array}{l}{[4,6,7,13,36,} \\
58]\end{array}$ \\
\hline & Iris pseudacorus & Black & $* \mathrm{ND}$ & Roots and rhizomes & {$[4,37]$} \\
\hline Juglandaceae & Juglans regia & $\begin{array}{l}\text { Green, grey, brown, } \\
\text { black }\end{array}$ & Anthraquinones & $\begin{array}{l}\text { The fleshy green } \\
\text { shell nuts are } \\
\text { known as brou. }\end{array}$ & {$[4,36,39]$} \\
\hline \multirow[t]{5}{*}{ Lamiaceae } & Clinopodium vulgare & Yellow & $*$ ND & Leaves & {$[4,39]$} \\
\hline & Lycopus europaeus & Black & $* \mathrm{ND}$ & $\begin{array}{l}\text { Aerial parts/roots } \\
\text { and rhizomes. }\end{array}$ & {$[4,39]$} \\
\hline & Rosmarinus Officinalis & ND & Flavones & $* \mathrm{ND}$ & {$[54]$} \\
\hline & Stachys officinalis & Brown & Tannins & Leaves & {$[4,39]$} \\
\hline & Thymus vulgaris & Yellow, orange & $\begin{array}{l}\text { Flavonoids } \\
\text { Luteolin }\end{array}$ & Entire plant & $\begin{array}{l}{[4,36,38,39,} \\
44]\end{array}$ \\
\hline \multirow[t]{2}{*}{ Lythraceae } & Lawsonia inermis & $\begin{array}{l}\text { Yellow to brown, red, } \\
\text { orange }\end{array}$ & $\begin{array}{l}\text { Naphthoquinone: Lawsone } \\
\text { N06 } 75480 \text { Lawsone. }\end{array}$ & Leaves & $\begin{array}{l}{[1,4,7,29,36} \\
39,42,43]\end{array}$ \\
\hline & Lythrum salicaria & Pink, red & $* \mathrm{ND}$ & Flowers & {$[4,39]$} \\
\hline \multirow[t]{2}{*}{ Malvaceae } & Alcea rosea "nigra" & Violet, blue & Anthocyanins & Rose petals & {$[4,6,39]$} \\
\hline & Hibiscus sabdariffa $L$. & Red & $\begin{array}{l}\text { Flavonoids } \\
\text { Anthocyanins }\end{array}$ & $\begin{array}{l}\text { Red chalices, fresh } \\
\text { or dried. }\end{array}$ & {$[6,17,38,42]$} \\
\hline \multirow[t]{2}{*}{ Moraceae } & Ficus carica & Yellow & $\begin{array}{l}\text { Flavonols-anthocyanins: } \\
\text { Quercitine }\end{array}$ & Leaves & $\begin{array}{l}{[4,34,36,38,} \\
39,42,43,51, \\
55]\end{array}$ \\
\hline & Morus nigra & Yellow, green, brown & $*$ ND & Leaves & $\begin{array}{l}{[4,36,38,39,} \\
43]\end{array}$ \\
\hline Myricaceae & Myrica gale & Yellow & ${ }^{*} \mathrm{ND}$ & Leaves & {$[4,36,58]$} \\
\hline Myrtaceae & Eucalyptus & Yellow to brown & Quercitin & Leaves & $\begin{array}{l}{[16,36,41,49-} \\
51]\end{array}$ \\
\hline Nymphaeaceae & Nymphaea alba & Grey to black & Tannins & Roots and rhizomes & $\begin{array}{l}{[1,4,5,7,13 \text {, }} \\
39]\end{array}$ \\
\hline Oleaceae & Ligustrum vulgare & Blue, yellow & Anthocyanin et Flavonoids. & $\begin{array}{l}\text { Leaves, bark, fruit } \\
\text { and branches }\end{array}$ & {$[1,4,5,7,39]$} \\
\hline Papaveraceae & Papaver rhoeas & Red, pink, violet & Anthocyanins et flavonoids & Flowers & {$[4,39,43,51]$} \\
\hline Phytolaccaceae & Phytolacca americana & Red, pink & Betalaines & Berries. & {$[4,24,39]$} \\
\hline Pinaceaes & Pinus $s p$ & Yellow to brown & Tannins and anthocyanins & Cones, fresh bark & {$[4,39]$} \\
\hline Poaceae & Sorghum bicolor & Sogho's Red carmin & Anthocyanins et tannins & Stems, leaf sheaths & {$[4,6,34]$} \\
\hline \multirow[t]{2}{*}{ Polygonaceae } & Polygonum aviculare & Yellow & Quercetol & Entire plant & {$[4,39,43,59]$} \\
\hline & Rumex crispus $L$. & Red, violet, orange & ${ }^{*} \mathrm{ND}$ & Roots and leaves & {$[4,39]$} \\
\hline
\end{tabular}




\begin{tabular}{|c|c|c|c|c|c|}
\hline Punicaceae & Punica granatum & Yellow & Ellagitannins & Bark and fruits & $\begin{array}{l}{[5,6,13,17} \\
36,38,39]\end{array}$ \\
\hline Resedaceae & Reseda luteola L. & Yellow & $\begin{array}{l}\text { Flavonoids: Luteolin } \\
\text { NY2: } 75580 \text { Luteolol, } \\
\text { 75580; } 75590 \text { Apigenol }\end{array}$ & $\begin{array}{l}\text { Flowers, aerial } \\
\text { parts. }\end{array}$ & $\begin{array}{l}{[4,6,13,39,} \\
51]\end{array}$ \\
\hline \multirow[t]{4}{*}{ Rhamnaceae } & Frangula alnus & Brown, blue, green & Flavonoids & Bark and berries & {$[4,6,15,39]$} \\
\hline & Rhamnus cathartica & $\begin{array}{l}\text { Yellow, brown, red, } \\
\text { green }\end{array}$ & Flavonoids Anthraquinones & Bark and berries & {$[4,39]$} \\
\hline & Rhamnus alaternus $L$. & Red, violer, orange & Flavonoids: Anthraquinones & Bark and berries & {$[6,15,39,41]$} \\
\hline & $\begin{array}{l}\text { Rhamnus lycioides } \\
\text { subsp. Oleides L. }\end{array}$ & Yellow & $\begin{array}{l}\text { Flavonols: } \\
\text { Anthraquinone/Rhamnétine } \\
\text { (CI75640), Quercétine } \\
\text { (CI75670). }\end{array}$ & $\begin{array}{l}\text { Unripe fruit, fresh } \\
\text { or dried }\end{array}$ & {$[15,39]$} \\
\hline \multirow[t]{2}{*}{ Rubiaceae } & $\begin{array}{l}\text { Galium aparine; } \\
\text { Galium verun (jaune), } \\
\text { Galium cruciata } \\
\text { galium mollugo }\end{array}$ & Red, pink & Anthraquinones & $\begin{array}{l}\text { Roots and rhizomes } \\
\text { and flowering tops }\end{array}$ & {$[4,7,39]$} \\
\hline & Rubia peregrina $L$. & Red & Anthraquinones & Roots and rhizomes & {$[15,39]$} \\
\hline Salicaceae & Salix alba & Brown, grey, black & Tannins & $\begin{array}{l}\text { Branches, leaves, } \\
\text { bark }\end{array}$ & {$[4,39]$} \\
\hline Solanaceae & Atropa bella-donna & Green & $* \mathrm{ND}$ & Leaves & {$[4,39,60]$} \\
\hline Thymelaeaceae & Daphne gnidium $L$. & Yellow & $\begin{array}{l}\text { Flavones/luteolin, } \\
\text { apigenine... }\end{array}$ & Aerial parts & $\begin{array}{l}{[6,36,39,41-} \\
43,51,59]\end{array}$ \\
\hline Urticaceae & Urtica dioica & Yellow & Flavonoids & Entire plant & $\begin{array}{l}{[4,7,38,39,} \\
43,53]\end{array}$ \\
\hline Vitaceae & $\begin{array}{l}\text { Vitis vinifera subsp. } \\
\text { sylvestris }\end{array}$ & $\begin{array}{l}\text { Purple, blue, grey, } \\
\text { yellow }\end{array}$ & Anthocyanin & Berries and fruits & $\begin{array}{l}{[4,24,34,36} \\
38,39]\end{array}$ \\
\hline Zingiberaceae & Curcuma longa $L$. & Yellow, orange & $\begin{array}{l}\text { Curcumine } \\
\text { NY3 75300: Curcumine }\end{array}$ & Root or rhizome & $\begin{array}{l}{[5,7,19,31} \\
36,48]\end{array}$ \\
\hline Zygophyllaceae & Peganum harmala & Pink to red & Anthraquinoniques & Seed & $\begin{array}{l}{[36,38,41-43,} \\
45,49,52,59, \\
61]\end{array}$ \\
\hline
\end{tabular}

* ND: not determined.

\section{CONCLUSION}

There are a large number of containers plant dye molecules. They are often known for their medicinal and aromatic properties. Most of the coloring plants have antibacterial activity. Interest in these plants will grow in the coming years and despite several studies conducted worldwide commercial exploitation is very limited since their users and their properties are quite low. Nevertheless, they represent an interesting option as products environmentally friendly.

\section{CONFLICTS OF INTERESTS}

\section{Declared none}

\section{REFERENCES}

1. Vankar PS. Chemistry of natural dyes. Resonance 2000;5:73-80.

2. Sivakumar V, Vijaeeswarri J, Lakshmi AJ. Effective natural dye extraction from different plant materials using ultrasound. Ind Crops Prod 2011;33:116-22.

3. Ben Mansour H, Latrach Tlemcani L. Les colorants naturels sont-ils de bons additifs alimentaires? Phytothérapie 2009; 7:202-10.

4. Garcia M, Saintenoy J, Colomb P, Service eco-conseil de la ville de Namur. Le jardin des plantes à couleurs. Juin ed. Vedria: Collection de plantes tinctoriales; 2014. p. 56.

5. Rajesh Y, Nita Y, Murli Dhar K. A review: dye yielding sources and their Importance. Int J Pharm Phytopharm Res 2014;6:241-8.

6. Cardon D. Le monde des teintures naturelles nouvelle edition. Vol. Nouvelle édition revue et augumentée. Paris Belin; 2014. p. 783.

7. Senthilkumar RP, Bhuvaneshwari V, Sathiyavimal S, Amsaveni R, Kalaiselvi M, Malayaman V. Natural colours from dyeing plants for textiles. Int J Biosci Nanosci 2015;2:160-74.

8. SIVA R. Status of natural dyes and dye-yielding plants in India. Curr Sci 2007;92:916-25.

9. Shahid M, Shahid-ul I, Faqeer M. Recent advancements in natural dye applications: a review. J Clean Prod 2013;53:310-31.
10. Viel C. Colorants naturels et teintures du XVIIe siècle à la naissance des colorants de synthèse. Revue d'histoire Pharmacie 2005;93:327-48.

11. Kumar Mathur A, Agarwal P. Application of natural dyes on textiles. Indian J Fibre Text Res 2009;34:384-99.

12. Zheng GH, Fu HB, Liu GP. Application of rare mordant for the dyeing with natural dyes. Korean J Chem Eng 2011;28:2148-55.

13. Saxena S, Raja ASM. Natural dyes: sources, chemistry, applications and sustainability issues. In: Roadmap to sustainable textiles and clothing, S. s. E. Muthu. Editor. Singapore: Springer: 2014. p. 37-80.

14. Madiélé AB, Quio Zhao JM, Thiery V, Agnaniet H, Brunet C, Graber $\mathrm{M}$, et al. Caractérisations analytiques des extraits colorants des plantes tinctoriales d'afrique centrale. Leb Sci J 2015;16:33-44.

15. Cuoco G. Etude chimique et caracterisation de principes colorants historiquement employes dans l'impression des indiennes en Provence, in Academie D'Aix-Marseille, Université d'Avignon; 2009.

16. Mongkholrattanasit R, Krystufek J, Wiener J. Dyeing and fastness properties of natural dyes extracted from eucalyptus leaves using padding techniques. Fiber Polym 2010;11:346-50.

17. El-Ghamri H, El-Agez T, Taya S, Abdel-Latif M, Batniji A. Dyesensitized solar cells with natural dyes extracted from plant seeds. Mater Sci-Poland 2014;32:547-54.

18. Guillermo C. L'evolution des colorants à travers les ages. Rev Fr Histotechnol 1998;11:9-38.

19. Tayade PB, Adivarekar V. Dyeing of cotton fabric with aluminum cyminumL. as a natural dye and its comparison with synthetic dye. J Text 2013;104:1080-8.

20. Jothia A. Extraction of natural dyes from African Marigold flower (Tadetes Ereectal) for textile coloration. Autex Res J 2008;8:49-53.

21. Shahid-ul I, Shahid M, Mohammad F. Perspectives for natural product based agents derived from industrial plants in textile applications-a review. J Clean Prod 2013;57:2-18. 
22. Nieto-Galan A. Natural dyestuffs and the kingdoms of nature. In: Colouring. Textiles RJ, Cohen RS, Gavroglu K. Editor. Netherlands: Springer; 2001. p. 1-41, 217.

23. Zhang B, Wang L, Luo L, King MW. Natural dye extracted from Chinese gall-the application of color and antibacterial activity to wool fabric. J Clean Prod 2014;80:204-10.

24. Schoefs B. Plant pigments: properties, analysis, degradation. Adv Food Nutr Res 2005;49:41-91.

25. Zhou Y, Falk CL, Vanleeuwen DM. Retail demand for natural dye plants and dye plant products: a conjoint analysis. J Int Food Agribus Mark 2012;24:66-75.

26. Giridhar P, Venugopalan A, Parimalan R. A review on annatto dye extraction, analysis and processing-A food technology perspective J Sci Res Rep 2014;3:327-48.

27. Réglement (UE) $n^{\circ} 94 / 36 / C E$ du Parlement européen et du conseil du 30 juin concernant les colorants destinés à être employés dans les denrées alimentaires, in $n^{\circ}$ L 237. 1994: Journal officiel de l'union européen; 1994. p. 17.

28. Réglement (UE) $n^{\circ} 1999 / 75 / C E$ de la Commission du 22 juillet établissant des critères de pureté spécifiques pour les colorants pouvant être utilisés dans les denrées alimentaires, in L 226. Journal officiel de l'union européen; 1999. p. 42.

29. Kumar Singh D, Luqman S, Kumar Mathur. A Lawsonia inermis L.-A commercially important primaeval dying and medicinal plant with diverse pharmacological activity: a review. Ind Crops Prod 2015;65:269-86.

30. Komboonchoo S, Bechtold T. Natural dyeing of wool and hair with indigo carmine (C. I. Natural Blue 2), a renewable resource based blue dye. J Cleaner Prod 2009;17:1487-93.

31. Boonsong $\mathrm{P}$, Laohakunjit N, Kerdchoechuen O. Natural pigments from six species of Thai plants extracted by water for hair dyeing product application. J Cleaner Prod 2012;37:93106.

32. Shalini S, Balasundara prabhu R, Prasanna S, Mallick Tapas K, Senthilarasu S. Review on natural dye sensitized solar cells: Operation, materials, and methods. Renewable Sustainable Energy Rev 2015;51:1306-25.

33. The essential chemical industry online, CIEC. Colorants; 2013. Available from: http://www.essentialchemicalindustry.org/ materials-and-applications/colorants.htlm. [Last accessed on 10 Apr 2016].

34. Andersen M, Jordheim M. Chemistry of flavonoid-based colors in the plant. In: Comprehensive natural products II chemistry and biology. Oxford: Elsevier; 2010. p. 547-614.

35. Vaes A. Projet FAO-TCP/MOR/3201 Renforcement des capacités locales pour développer les produits de qualité de montagne-cas du Safran. Programme de cooperation technique Maroc; 2008. p. 31.

36. Hmamouchi M. Plantes alimentaires aromatiques condimentaires médicinales. In: Identification of wild food and non-food plants in Mediterranean region. VHe Heywood, Skoula M. Editor. Chania: CIHEAM. 1997. p. 89-108.

37. Fennane M. Ibn Tattou M, Ouyahya A, Oualidi J. Ed. Flore pratique du Maroc. Vol. II. Rabat: Institut Scientifique série Botanique; 2007. p. 38.

38. Benkhnigue O, Ben Akka F, Salhi S, Fadli M, Douira A, Zidane L. Catalogue des plantes médicinales utilisées dans le traitement du diabète dans la région d'Al haouz-rhamna (Maroc). J Anim Plant Sci 2014;23:3539-68.

39. Fennane M, Ibn Tattou M, Mathez MJ, Ouyahya A, Oualidi J. Flore pratique du Maroc. Vol. 1. Rabat: Institut Scientifique Université Mohammed V; 1999.

40. El hilah F, Ben akka F, Bengueddour R, Rochdi A, Zidane L. Étude ethnobotanique des plantes médicinales utilisées dans le traitement des affections dermatologiques dans le plateau central marocain. J Appl Biosci 2016;98:9252-60.

41. Lahsissene H, Kahouadji A. Analyse ethnobotanique des plantes médicinales et aromatiques de la flore marocaine: cas de la région de Zaër. Phytothérapie 2010;8:203-9.

42. El Hafian M, Benlamdini N, Elyacoubi H, Zidane L, Rochdi A. Étude floristique et ethnobotanique des plantes médicinales utilisées au niveau de la préfecture d'Agadir-Ida-Outanane (Maroc). J Appl Biosci 2014;81:7198-213.

43. Benkhnigue O, Zidane L, Fadll M, Elyacoubi H, Rochdi A, Douira A. Etude ethnobotanique des plantes médicinales dans la région de mechraâ bel ksiri (Région du Gharb du Maroc). Acta Bot Barc 2010-2011;53:191-216.

44. Mikou K, Rachiq S, Jarrar Oulidi A. Étude ethnobotanique des plantes médicinales et aromatiques utilisées dans la ville de Fès au Maroc. Phytothérapie 2016;14:35-43.

45. Ben Mostafa $\mathrm{S}$, Haloui $\mathrm{B}$, Berrichi $\mathrm{A}$. Contribution à l'étude de la végétation steppique du Maroc Oriental: transect jerradafiguig. Acta Bot Malac 2001;26:295-301.

46. Michel C, Ruellan A. L'agriculture et les fôrets au Maroc. In: Les cahiers de la recherche agronimique. Madrid: Excursion au Maroc; 1967. p. 103-40,24.

47. Fadi Z. Le romarin rosmarinus officinalis Le bon procédé d'extraction Pour un effet thérapeutique optimal, in Universite mohammed v, Faculte de Medecine et de Pharmacie Rabat; 2011. p. 210.

48. Selvam RM, Athinarayanan G, Nanthini AUR, Singh AJAR, Kalirajan K, Selvakumar PM. Extraction of natural dyes from Curcuma longa, Trigonella foenum graecum and Nerium oleander, plants and their application in antimicrobial fabric. Ind Crops Prod 2015;70:84-90.

49. Hseini S, Kahouadji A. Etude ethnobotanique de la flore médicinale dans la région de Rabat (Maroc occidental). Lazaroa 2007;28:79-93.

50. Tahri N, El Basti A, Zidane L, Rochdi A, Douira A. Etude ethnobotanique des plantes medicinales dans la province de settat (Maroc). Kastamonu Univ. J Forestry Faculty 2012;12:192-208.

51. Orch $\mathrm{H}$, Zidane L, Douira A. Contribution à la connaissance de la flore vasculaire du massif d'Izarène (Nord Ouest Maroc). J Anim Plant Sci 2013;10:3093-112.

52. Mehdioui R, Kahouadji A. Etude ethnobotanique auprés de la population riveraine de la forêt d'Amsitténe: cas de la Commune d'Imi n'Tlit (Province d'Essaouira). Bull de l'Institut Sci Rabat Section Sci de la Vie 2007;29:11-20.

53. Fougrach H, Badri W, Malki M. Flore vasculaire rare et menacée du massif de Tazekka (région de Taza, Maroc). Bull de l'Institut Sci Rabat Section Sci de la Vie 2007;29:1-10.

54. Meliha BO, Ezgi A. Ecological dyeing with some plant pulps on woolen yarn and cationized cotton fabric. J Clean Prod 2012;32:1-9.

55. Thomas V. Les plantes tinctoriales et leurs principes colorants. Paris: Iris-liliad-Université Lille; 1901. p. 196.

56. Chevalier A. Les plantes coloniales utiles que l'on peut cultiver en France. Rev Bot Appl Agric Colon 1943;23:177-96.

57. Kremer Pigment. Datasheet 36018 Chrozophora, Folium cloth; 2008. p. 1-5.

58. Zrira S. Le marché des plantes aromatiques et médicinales au Maroc. Département des Sciences Alimentaires et Nutritionnelles, Institut Agronomique et Vétérinaire Hassan II, B. P. 6202, Rabat Instituts, Rabat, Maroc; 2006.

59. Salhi S, Fadli M, Zidane L, Douira A. Etudes floristique et ethnobotanique des plantes médicinales de la ville de Kénitra (Maroc). Lazaroa 2010;31:133-43.

60. Zekkour M. Les risques de la phytothérapie, Monographies des plantes toxiques les plus usuelles au Maroc, in Universite mohamed v-souissi. Faculte de Medecine et de Pharmacie: Midelt; 2008. p. 125.

61. Tahrouch S, Rapior S, Mondolot-Cosson L, Idrissi-Hassani LA Bessière JM, Andary C. Peganum harmala: source combinée d'arômes et de colorants. Rev Biol Biotechnol 2002;2:33-7.

\section{How to cite this article}

- Imane Alouani, Mohammed Oulad Bouyahya Idrissi, Mustapha Draoui. Review: from screening to the application of Moroccan dyeing plants: chemical groups and botanical distribution. Int J Pharm Pharm Sci 2016;8(10):21-31. 